\title{
ALGUMAS IMAGENS DO CATOLICISMO NOS CONTOS DE H. P. LOVECRAFT ${ }^{1}$
}

Alfredo Bronzato da Costa Cruz (PPGH/UERJ)

Recebido em 06 mar 2017. Alfredo Bronzato da Costa Cruz é doutorando em Aprovado em 30 mar 2017. História Política no Programa de Pós-Graduação em História da Universidade do Estado do Rio de Janeiro (PPGH/UERJ, 2015-). Mestre em História Social pelo Programa de Pós-Graduação em História da Universidade Federal do Estado do Rio de Janeiro (PPGH/UNIRIO, 2011-2013). Bacharel e Licenciado em História pela Pontifícia Universidade Católica do Rio de Janeiro (PUC-Rio, 2005-2009).

Resumo: Partindo da leitura de três contos de $\mathrm{H}$. P. Lovecraft - "Ar frio" (1926/1928), "Sonhos na Casa da Bruxa" (1932/1933) e "O assombro nas trevas" (1935/1936) - procurou-se tecer algumas considerações a respeito da representação do catolicismo na obra ficcional deste autor. Concluiu-se que a marca desta é, antes do mais, uma interessante ambiguidade.

Palavras-chave: H. P. Lovecraft; Catolicismo romano; Religião e literatura; Representação.

1 Uma considerável parte deste paper foi originalmente apresentada em 30 de março de 2015, com o título de Ambiguidades do catolicismo no gótico americano: "Ar frio" (1926) e "O assombro nas trevas" (1935), de H. P. Lovecraft, como uma comunicação na 1a sessão do simpósio temático Estudos do gótico: as faces do gótico no mundo, realizado no âmbito do 6 Encontro Nacional, O Insólito como Questão na Narrativa Ficcional (UERJ, Rio de Janeiro). Sou imensamente grato aos gentis e instigantes comentários que a respeito de minha fala fez nesta ocasião o Prof. Dr. Fernando Monteiro de Barros (UERJ). Título do artigo em inglês: Some images of Catholicism in the stories of H. P. Lovecraft. 


\begin{abstract}
Starting from the reading of three stories by H. P. Lovecraft - "Cool Air" (1926/1928), "The Dreams in the Witch House" (1932/1933) and "The Haunter of the Dark" (1935/1936) - it was made some considerations about the representation of catholicism in this author's fictional work. It was concluded that one main characteristic of this representation is an ambiguity.
\end{abstract}

Keywords: H. P. Lovecraft; Roman Catholicism; Religion and literature; Representation.

O presente texto aborda algumas das imagens do catolicismo na obra de Howard Philips Lovecraft (1890-1937) e, a partir delas, procurou-se elencar de forma sumária, certas ideias a respeito da representação deste movimento religioso, ou melhor, de alguns de seus elementos considerados mais típicos, na literatura gótica e fantástica de terror norte-americana de um modo mais geral. A escolha de tratar deste tema a partir de Lovecraft exige alguma explicação, que se oferecerá pouco mais adiante; por agora, observa-se que um tratamento extensivo de sua obra seria impossível no curto espaço cá disponível, além de inviável no atual estágio de minha pesquisa sobre o assunto. Daí a estratégia de concentrar-me em alguns poucos indícios, pinçados à guisa de amostragem por algumas de suas características mais evidentes, ou seja, considerados como representativos de tendências mais amplas. Neste sentido, o presente estudo tem um caráter exploratório que conscientemente mimetiza o do paper de lan Almond sobre a representação do Islã nos textos do mesmo Lovecraft (2004/2015). 


\section{E OS INQUILINOS REZAVAM AS CONTAS DE SEUS ROSÁRIOS: “AR FRIO" (1926/1928)}

"Ar frio" foi a última das histórias escritas por Lovecraft durante o seu período nova-iorquino, e disputa com "O horror em Red Hook" (1925/1927) o título de melhor delas. ${ }^{2}$ A partir da confissão de um homem que teme as lufadas de ar frio, a elas respondendo "como os outros respondem a um odor desagradável", esta estória redigida aparentemente no fim de fevereiro de 1926 trata do que acontece quando certo Sr. Muñoz, que requeria um ambiente constantemente fresco em seu quarto de apartamento na megalópole americana, tem de lidar com o ar-condicionado que não funciona; e o narradorprotagonista, seu vizinho temporário, por ele salvo de um infarto, não é capaz de encontrar quem conserte o aparelho. O caso é que Muñoz, que havia sido um médico ilustre em Barcelona e dizia-se portador de uma estranha e incapacitante doença, de fato estava morto há quase duas décadas; o frio intenso, as fortes substâncias químicas e os odores de especiarias e incenso eram vestígios dos expedientes que empregava para retardar ou camuflar seu progressivo apodrecimento. Quando a temperatura do apartamento começa a aumentar, nem todo o gelo disponível nas lojas da vizinhança foi capaz de preservá-lo até o conserto do ar-condicionado. Ao retorno do protagonista à casa, trazendo consigo a peça necessária para o reparo do aparelho e um par de capacitados mecânicos, toda sua "esperança de que ainda houvesse tempo" se desfez:

A casa estava em pandemônio, e acima das vozes exaltadas escutei alguém rezando em uma voz de

2 Nas datas mencionadas entre parênteses logo em seguida aos títulos dos contos, a primeira refere-se ao ano da redação da estória, enquanto a segunda indica o de sua primeira publicação. 
baixo profundo. Havia algo demoníaco no ar, e os inquilinos rezavam as contas de seus rosários enquanto sentiam o cheiro fétido que saía por baixo da porta fechada do médico. 0 desocupado que [...] arranjara [para levar gelo aos aposentos do Dr. Muñoz] havia fugido em meio a gritos e com o olhar vidrado logo após a segunda remessa de gelo; talvez como resultado de uma curiosidade excessiva. É claro que não poderia ter chaveado a porta atrás de si; mas nesse instante ela estava trancada, provavelmente pelo lado de dentro. Não se ouvia som algum exceto um inominável gotejar lento e viscoso... (LOVECRAFT, 2012, p.37)

Ardilosamente se consegue abrir a porta; todas as portas e janelas de todos os outros quartos já estavam abertas ao máximo possível por causa do mau cheiro ambiente; os narizes são protegidos por lenços; um grupo adentra os aposentos do Sr. Muñoz, iluminado pelo sol da tarde que começava. Um rastro escuro e viscoso se estendia da porta aberta do banheiro até a do corredor, e de lá para escrivaninha, onde uma poça abominável havia se acumulado; a partir daí, seguia até o sofá, acabando "de forma indizível", em algo que o narrador afirma não conseguir e não ousar descrever. Encontra-se também um último escrito do médico espanhol, onde confessava que, antes da dissolução final, já estava clinicamente morto fazia dezoito anos; no "papel coberto por manchas grudentas [...] as palavras nauseantes pareciam inacreditáveis sob o brilho dourado do sol, em meio ao rumor dos carros e dos caminhões vindos da movimentada 14th Street" (LOVECRAFT, 2012, p.38).

Fansworth Wright, que foi diretor da Weird Tales de 1924 a 1940, período áureo desta revista, e que aí publicou regularmente estórias de Lovecraft e de autores de seu círculo, recusou-se a 
dar a público "Ar frio", em decisão que Sunand Tryambak Joshi, importante estudioso da vida e da obra lovecraftiana, considera tão incrível quanto inexplicável, já que se tratava justamente do "tipo de conto macabro de que teria gostado" (2014, p.265). Joshi aventa a possibilidade de que Wright talvez estivesse com receio do tipo de recepção que poderia ter a conclusão repugnante da estória, mas, de qualquer forma, Lovecraft foi obrigado a vender este trabalho à Tales of Magic and Mystery, publicação menor, de vida bastante curta, onde apareceu apenas em março de 1928.

As referências literárias empenhadas na composição do conto, de acordo com afirmação do próprio Lovecraft em carta a Henry Kuttner (1990, p.21), foram os "Fatos no caso do Sr. Valdemar", de Edgar Allan Poe, e, mais ainda, "A novela do pó branco", de Arthur Machen, estória na qual um jovem e desafortunado estudante de Direito faz uso de uma droga que o transforma, afinal, em "uma massa escura e putrefeita, fervilhando em corrupção e meio decomposta, nem líquida, nem sólida, mas derretendo e mudando de forma" (LOVECRAFT, 1987, p.93). O apartamento no qual se desenrola o enredo foi baseado no prédio em arenito marrom, n. 317 da West 14th Street, em Manhattan, em que George Kirk, um conhecido de Lovecraft, viveu e que foi por ele bastante frequentado durante o ano de 1925. De acordo com Joshi, o conto é uma "bem-sucedida evocação do horror encontrado [pelo tradicional e provinciano Lovecraft] no burburinho indefinido da única verdadeira megalópole norte-americana" do período; trata-se efetivamente de mais uma de suas "histórias racistas" que serviram como

[...] válvula de escape para a raiva e o desespero surgidos de fazer a experiência de uma cidade que, 
se antes havia parecido glamorosa, passou a aplicar repetidos golpes na [sua] autoestima ao negar-lhe um trabalho apesar de suas habilidades e ao forçálo a refugiar-se num buraco dominado pelo crime e infestado de ratos. (2014, p.257-265)

Essa abordagem que aproxima muito imediatamente vida e obra do autor parece-me inadequada e, de toda forma, menos rentável para os propósitos do presente texto; nisto, faz-se vênia à posição de Luiz Costa Lima, que no prefácio de um de seus livros trata de ressaltar que

[...] não só a escrita da história depende e se diferencia pela maneira como se configura - ou seja, pela maneira como dispõe os dados factuais que seleciona -, como também, e, sobretudo, de que o texto ficcional, em vez de dar as costas à realidade, a dramatiza e metamorfoseia; a ficção converte em volume e descontinuidade o linear com que, na vida cotidiana, dispomos o mundo; o mundo, isso que está aí; a ficção transtorna as dimensões do mundo, em vez de pôr o mundo entre parênteses. (2003, p.18 - grifo no original)

Ora, isto considerado, a extensão do espaço do terror do ermo e dos povoados menores para o interior da cidade grande não parece apenas o reflexo das experiências negativas de Lovecraft, mas, em diálogo com estas, a continuidade ou retomada de um lugar-comum esboçado, por exemplo, na primeira parte da "Novela da chancela negra", de Machen, conto de 1895 que parece ter tido uma extraordinária influência temática e formal sobre a produção do autor de "Ar frio" (MACHEN, 2007, p.69-73; CRUZ, 2014; ALMEIDA, 2008, p.37) que, contudo, não menciona a relação Lovecraft-Machen. De toda forma, o narrador-protagonista da 
estória em análise, que declara ter encontrado o horror "em pleno sol do meio-dia, no rumor de uma metrópole e em meio a uma pensão rústica e ordinária", enfatiza logo a seguir que a casa na West 14th Street, "uma mansão de quatro andares em arenito, construída, a julgar pela aparência, no fim da década de 1840, com detalhes em madeira e mármore cujo esplendor manchado e encardido denunciava a decadência em relação a níveis de opulência outrora elevados", desagradava-Ihe de fato "muito menos do que as outras" pensões disponíveis em sua miséria: "o piso era limpo, as roupas de cama bastante decentes e a água quente não ficava fria ou desligada com muita frequência [...] um lugar tolerável para hibernar até que [...] pudesse voltar de fato à vida" (LOVECRAFT, 2012, p.29-30). Esse caráter relativamente aprazível faz com que se esboce no quadro algo mais matizado do que em "O horror em Red Hook", na qual se contrapõem com dureza, de um lado, uma população de imigrantes que Lovecraft descreve como "um emaranhado e um enigma incorrigível [...] uma babel de sons e sujeira lançando exclamações estranhas [...] hordas de vagabundos [que] vagam sem destino gritando e cantando pelas vielas e ruas movimentadas [...] rostos morenos e marcados pelo pecado", com, de outro, a "felicidade passada" de "um quadro mais aprazível, com marinheiros de olhos claros" (LOVECRAFT, 2007, p.82-93).

Como parte da conveniência relativa da mansão na West 14th Street, inclui-se também a presença da senhoria, "uma espanhola vulgar e quase barbada que atendia pelo nome de Herrero", que não o aborrecia com fofocas ou críticas a respeito da luz que permanecia acessa em seu quarto até tarde; e dos demais inquilinos, "quietos e indiferentes quanto se podia desejar, sendo a maioria deles 
espanhóis só um pouco acima da maior grosseria e da maior vileza" (LOVECRAFT, 2012, p.30). Conforme "uma atmosfera de pânico cada vez maior e mais inexplicável dava a impressão de pairar sobre o apartamento" do (já finado) médico espanhol, na medida em que o narrador-protagonista de "Ar frio", em gratidão pelo auxílio prestado em uma emergência, assumia os seus cuidados, "a sra. Herrera passou a fazer o sinal da cruz ao vê-lo" (LOVECRAFT, 2012, p.35); quando do agravamento e expansão final dos odores da putrescência do Sr. Muñoz, tanto a senhoria quanto seus grosseiros e vis inquilinos reagem de acordo com o mais previsível dos estereótipos norteamericanos a respeito dos povos latinos, alternando gritaria e orações à Virgem (PIKE, 1998, p.75-86). Tais imagens decerto não são imanentes, mas - como bem demonstrou Edward Said no que se refere às representações do oriente produzidas e geridas pelos orientalistas europeus (2007) - o produto de complexos mecanismos socioculturais e político-econômicos; de fato, no que concerne à peculiar associação de passionalidade, desordem moral e expressão de devoção, o clichê havia sido forjado e difundido por toda uma imensa literatura apologética que, desde o meado do século XIX, defendia a necessidade do envio de missões protestantes não só para as terras que antes faziam parte dos impérios coloniais ibéricos, mas para a própria Europa mediterrânica (CROWE, 1850; ANGELL, 1909; HAY, 1920; PIEDRA, 2006, v. 1, cap. 1-2). São, contudo, esta senhoria e estes inquilinos quem, curiosos e corajosos, acompanham o narrador-protagonista na invasão ao quarto tumular do médico, seu conterrâneo, antes de correr "em pânico daquele aposento infernal para balbuciar suas histórias incoerentes na delegacia mais próxima" (LOVECRAFT, 2012, p.38). 


\section{INSTAVA O JOVEM CAVALHEIRO A USAR SEU CRUCIFIXO DE CORRENTE NIQUELADA: "SONHOS NA CASA DA BRUXA" (1932/1933)}

Em julho de 1933, a revista Weird Tales publicou de Lovecraft o conto "Sonhos na Casa da Bruxa", escrito nos meses de janeiro e fevereiro do ano anterior. Seu enredo é bem conhecido: quando Walter Gilman, estudante de matemática avançada e folclore na Universidade de Miskatonic, aluga um quarto de ângulos estranhos no sótão de uma mansão que se dizia mal-assombrada, começa a experimentar uma série de sonhos bizarros, nos quais a fronteira entre delírio e vigília parece-lhe cada vez mais tênue; nos mais realistas destes, encontra Keziah Mason, uma sobrevivente dos julgamentos das bruxas de Salem, e seu grotesco familiar, Brown Jenkins, um grande roedor com certas características humanoides. Depois de contatos cada vez mais próximos com coisas que a humanidade deveria desconhecer, Gilman acaba morrendo de maneira pavorosa, mas não sem antes ter uma ambígua participação em um ritual no qual se sacrificou um bebê sequestrado; depois disso, a mansão é abandonada por seus outros moradores. O desfecho da narrativa é situado por Lovecraft pouco antes da própria redação do conto:

Em março de 1931, um vendaval destruiu o telhado e a grande chaminé da abandonada Casa da Bruxa, de modo que um caos de tijolos esmigalhados, os sarrafos enegrecidos, telhas cheias de musgo e tábuas e vigas podres desmoronaram dentro do sótão, arrebentando-lhe o piso. Todo o andar estava entulhado com os escombros, mas ninguém se incomodou em mover uma palha até o inevitável desmoronamento da decrépita 
estrutura. O derradeiro passo veio em dezembro, e foi quando relutantes e apreensivos operários vieram desentulhar o antigo quarto de Gilman que o falatório começou. Entre os detritos que tinham desmoronado através do velho teto inclinado havia várias coisas que fizeram os operários pararem 0 trabalho e chamarem a polícia. A polícia, por sua vez, chamou o médico legista e vários professores da universidade. (LOVECRAFT, 2013, p.157)

Sobre o sótão havia ossos, muitos em mau estado, mas claramente humanos e alguns recentes, em conflito com o período em que o esconderijo, onde estavam, havia sido lacrado. Havia fragmentos de muitos livros e papéis, junto com o pó amarelado deixado pela desintegração total de velhas páginas; todos pareciam tratar de magia negra, terem sido escritos durante um período de séculos por uma mesma pessoa, e alguns também indicavam serem não muito antigos. Havia variados objetos de artesanato de forma, proveniência e função desconhecida, entre os quais uma peça similar ao ídolo metálico que antes Gilman havia doado ao museu universitário, e uma tigela esmagada de metal, ornada com hieróglifos grotescos e apresentando sinistras manchas marrons em seu interior. Enquanto os arqueólogos e antropólogos conferenciavam a respeito de tais objetos, sem conseguir localizálos em alguma sequência cultural conhecida,

Os estrangeiros e avós crédulas são igualmente tagarelas no que se refere ao crucifixo moderno com corrente de níquel quebrada encontrado em meio aos escombros e arrepiantemente identificado por Joe Mazurewicz como o que ele tinha dado ao pobre Gilman muitos anos antes. Uns creem que este crucifixo foi arrastado pelos ratos até o desvão 
fechado, enquanto outros acham que devia estar em algum canto no chão do velho quarto de Gilman todo esse tempo. Outros ainda, inclusive Joe, defendem teorias selvagens e fantásticas demais para receberem sóbria credibilidade. (LOVECRAFT, 2013, p.158)

Quando a parede inclinada do quarto foi arrancada, o espaço triangular antes selado entre essa partição e a parede norte da casa revelou ser um verdadeiro ossuário infantil, contendo tanto restos recentes quanto outros muito antigos, de um período tão remoto que quase já estavam inteiramente deteriorados. Ao fundo desta sinistra acumulação, encontrou-se um punhal grande, obviamente antigo e ornado de modo grotesco. Junto a um amontoado de tijolos cimentados da arruinada chaminé, encontrou-se ainda

[...] o esqueleto parcialmente esmagado de um enorme rato deformado, cujas anormalidades anatômicas são, até hoje, tema de debates e fonte de singular reticência entre os membros do departamento de anatomia comparada da Universidade de Miskatonic. Muito pouco a respeito desse esqueleto foi divulgado, mas os trabalhadores que o encontraram sussurravam horrorizados sobre os longos pelos marrons aos quais estava ligado. Os ossos das patas minúsculas, comentava-se, denotam características preênseis mais típicas de um macaco pequeno que de um rato; enquanto o crânio diminuto, com suas selvagens presas amarelas, é de uma anomalia inigualada, parecendo de certos ângulos, uma paródia monstruosamente degradada de um crânio humano em formato muito pequeno. Os trabalhadores benzeram-se de medo quando deram com tal blasfêmia, porém mais tarde acenderam velas de gratidão na Igreja de Santo 
Estanislau, por sentirem que nunca mais os abafados, estridentes e espectrais risos seriam ouvidos novamente. (LOVECRAFT, 2013, p.158159)

Nesta última frase, há dois elementos interessantes a serem destacados na presente investigação. 0 primeiro é o conceito de blasfêmia, de coisa blasfema, diante do qual os operários envolvidos no desmonte da Casa da Bruxa se benzem. Tradicionalmente, blasfemar possui três conotações distintas, ainda que conexas: 1. caluniar, falar contra (principalmente Deus ou algo sagrado); 2. ultrapassar um limite (estabelecido pela natureza e/ou pela divindade); 3. afirmar uma opinião diversa e/ou contrária à ortodoxia religiosa estabelecida (principalmente no que tange à natureza de Deus e/ou da Sua Criação). De acordo com o que foi destacado por Robert M. Price (1981), Lovecraft também conheceu e utilizou esta noção em seus sentidos mais convencionais de falar ou agir contra Deus e afirmar uma opinião a Seu respeito que é diversa do que estabeleceu a institucionalidade religiosa. ${ }^{3}$ Entretanto, de forma mais corriqueira, utilizou blasfemo como sinônimo de abominável ou monstruoso, no sentido de que se trata de algo que borra as categorias classificatórias estabelecidas e por isso é ultrajante. Como destacou Mary Douglas (2010), puro e santo é o que se conforma no interior do que uma dada sociedade determina como sendo sua categoria de criação, seu lugar natural, enquanto abominável 3 No primeiro caso, mais simples, no comentário que faz no seu 0 horror sobrenatural na literatura à peça Deuses da montanha de Lorde Dunsany: "[...] e por fim os sacrílegos aventureiros são transformados em estátuas de jade pelas próprias estátuas ambulantes cuja santidade profanaram" (LOVECRAFT, 1987, p.98). No segundo, mais complexo e abrangente, no fato do Necronomicon, que reiteradamente referencia como tomo blasfemo (PRICE \& ALETTI, 2002) por causa de suas doutrinas nada ortodoxas e das "terríveis consequências" que podem advir de sua leitura, ser igualmente tido como herético e, portanto, "severamente proibido [...] por todos os ramos das organizações eclesiásticas" (LOVECRAFT, 2013, p.84). 
- monstruoso - é confundir/transgredir os limites identificáveis (CARROLL, 1999, p.50). Lovecraft, que era ateu, não associou nunca a blasfêmia a um julgamento e punições divinas, mas ao fato de que o buscador de conhecimento oculto, ao querer ultrapassar os liames comuns da realidade, é destruído justamente pelo que ele procura (e encontra) na medida em que isto se coloca para além de sua capacidade comum de sentir e entender; blasfemo seria o que supõe "uma suspensão ou uma derrogação particular das imutáveis leis da Natureza, que são a nossa única defesa contra as agressões do caos e dos demônios do espaço insondado" (LOVECRAFT, 1987, p.5). De outra parte, nas orações dos operários que revolvem os escombros da Casa das Bruxas, contudo, concorrem os três sentidos tradicionais do termo, que, neste caso, concordam com o juízo do próprio Lovecraft: o esqueleto por eles encontrado viola as leis da Natureza, por isso gera discussão e receio entre os acadêmicos que lidam com ele, mas também é uma afronta à sensibilidade religiosa dos que o encontram, porque é uma transgressão às fronteiras que Deus teria estabelecido para as espécies e coloca em xeque as ideias cristãs a respeito do tipo de coisa que existe no mundo. ${ }^{4}$

4 Como observou Douglas no capítulo "As abominações do Levítico", a noção de santidade e naturalidade como pureza encontra-se particularmente bem exemplificada neste livro da Bíblia Hebraica. Por exemplo. Lv 18:23: "[...] Não te deitarás com animal algum; tornar-te-ias impuro. A mulher não se entregará a um animal para se ajuntar com ele. Isto é uma impureza". E Lv 19:19: "[...] Guardareis os meus estatutos. Não jungirás dois animais de espécie diferente no teu rebanho; não semearás no teu campo duas espécies de sementes e não usaras veste de duas espécies de tecido". Os exemplos poderiam se multiplicar muitíssimo. Toda a moralidade sexual das religiões abraâmicas foi definida nessa base: assim como a bestialidade ignoraria a diferença humano/animal, o incesto ultrapassaria os limites pais/filhos e a homossexualidade violaria a fronteira macho/fêmea. Do mesmo modo, as regras dietéticas que, grosso modo foram abolidas pelo cristianismo (Por exemplo, Mt 15:10-20 e At 10:9-16), possuem importante papel no Islã e no judaísmo. Os animais que não são kosher são justamente aqueles que desafiam as categorias taxonômicas vigentes entre os antigos hebreus: aos mariscos não se considerava verdadeiros peixes porque, embora vivessem no mar, não têm barbatanas, nem escamas; aos porcos não se consideravam verdadeiro gado porque, apesar de seus cascos fendidos, não ruminam. (Todas as citações bíblicas deste paper são referidas a partir da Bíblia 
Como segundo elemento a ser destacado, pode-se ir além e dar uma especificação a esta sensibilidade religiosa que estaria sendo ultrajada pela existência mesmo de Brown Jenkins. Arkham, onde se encontraria a Casa da Bruxa, é uma cidade fictícia de Massachusetts, criada por Lovecraft e recorrente nas suas estórias compostas entre 1921 e 1935 (JOSHI \& SCHULT, 2001, p.6-7). A Igreja de Santo Estanislau que ele aí localiza, um templo na qual se acendem velas ao padroeiro, é uma referência bastante precisa. Em primeiro lugar, o acendimento de velas à imagem de um santo como sinal de gratidão por uma circunstância qualquer, remetenos de imediato a um costume católico; um livro recentemente publicado descreve o cristianismo no norte europeu pósreforma protestante como marcada justamente pelo cheiro de velas apagadas, o que é mais do que apropriado, posta a dura condenação dos reformadores a este tipo de prática (HEIDING \& NYMAN, 2016). ${ }^{5}$ No nordeste norte-americano do início do século $\mathrm{XX}$, ainda tão marcado pela herança puritana, esse costume devia parecer remeter não só a algo exótico, mas também supersticioso; parece verossímil acreditar que Lovecraft registrava este costume dos operários justamente para marcar seu caráter de estrangeiros. Ora, o onomástico do templo no qual tais velas são acendidas confirma a hipótese: São Estanislau de Szczepanów (1030-1079), bispo de Cracóvia e mártir, padroeiro da Polônia e imensamente popular na diáspora polonesa, principalmente nos EUA, onde muitas das associações de mútua-ajuda e igrejas consagradas no século XIX para atender aos imigrantes católicos do Leste Europeu lhe de Jerusalém. Coordenação editorial de J. Bortolini; tradução de E. M. Balanci et alli. São Paulo: Paulus, 2002).

5 Cf. CALVINO, 1985, t. 1, cap. 11, 13-16, pp. 119-122. A respeito, também THOMAS, 1991, cap. 2-3, e DUFFY, 2005 (em perspectiva muito mais próxima de HEIDING \& NYMAN). 
foram dedicadas (KUZMONVÁ, 2010; BUCZEK, 1976). O catolicismo romano está presente na América do Norte desde os séculos XV e $\mathrm{XVI}$, mas a hegemonia cultural protestante eventualmente fez com que esta religião fosse associada a elementos estrangeiros - como o Sr. Dombrowski, o senhorio polonês de Gilman, Joe Mazurewicz e Paul Choynski, seus inquilinos e conterrâneos, e o Sr. Desrochers, o franco-canadense que morava no quarto logo abaixo daquele alugado pelo desafortunado estudante. ${ }^{6} \mathrm{Em}$ um momento tão recuado quanto julho de 1790, o presidente George Washington retornou uma carta que vários anglo-católicos proeminentes de Maryland haviam escrito para felicita-lo pelo sucesso da revolução patriótica; entre estes, encontrava-se D. John Caroll, SJ, que alguns meses antes havia sido consagrado bispo da recémformada diocese católico romana de Baltimore. Neste documento, Washington lembrou-se do apoio que o novo país havia recebido dos católicos durante a recente Guerra de Independência (17751783), especialmente o papel que eles tiveram em assegurar o apoio da França e da Espanha aos revolucionários. D. Caroll, cujo irmão Charles participou do Primeiro Congresso Continental (1774) representando Maryland e foi o único católico a assinar a Declaração de Independência dos EUA, era um prelado abertamente comprometido com uma Igreja com identidade norte-americana; quando de sua morte em 1815, um catolicismo autóctone estava

6 Para um acessível resumo das relações entre religião e política na história dos Estados Unidos, ver SILVA, 2009 - que, contudo, infelizmente me parece um pouco ingênuo. Mesmo exaltado, ao afirmar, por exemplo, na conclusão de seu texto (p.112) que "[...] Ao longo dos séculos, desde o início, a tolerância e o direito à dissidência sempre foram mais fortes do que a intolerância e o fanatismo. Foi a mistura do alto grau de religiosidade que sempre esteve presente na vida americana com a influência igualmente penetrante e duradoura do lluminismo na sociedade dos Estados Unidos que deu características únicas de sutileza e dinamismo ao modo como a religião e a política [aí] estabelecem sua relação dialética e complexa". 
firmemente estabelecido (IRVIN \& SUNQUIST, 2015, p.587-589). Por outro lado, havia uma resistência muito grande de setores protestantes para que os católicos - mesmo os de pura cepa anglo-saxônica, vindos à América como refugiados das reformas henrique-elizabethanas - fossem admitidos em âmbito de igualdade na nova nação. Muitos dos colonos que haviam lutado na Guerra dos Sete Anos (1756-1763), assim como seus filhos e netos, tendo-se engajado nos selvagens confrontos entre, de um lado, os ingleses dos dois lados do Atlântico e, do outro, franceses e espanhóis católicos apoiados por grandes contingentes de indígenas convertidos a esta religião, mantinham acessas as mais flamejantes críticas desenvolvidas pelos reformadores protestantes à Igreja de Roma e, de fato, engajaram-se no confronto contra sua metrópole não por qualquer consideração de ordem política e econômica, mas pela convicção de que a Igreja Anglicana sucumbira ou estava a ponto de sucumbir aos costumes papistas (PIKE, 1998, p.76). 0 discurso do catolicismo como um elemento estrangeiro no corpo nacional em formação, que ativamente se apropriou dos clichês referentes aos jesuítas como infiltradores profissionais e do Papa como um monarca estrangeiro disposto a estabelecer um domínio temporal de âmbito global, foi grandemente corroborado pela experiência da segunda metade do século XIX e início do século XX, quando o país recebeu significativos contingentes de imigrantes católicos (irlandeses, italianos, poloneses, espanhóis, entre outros), que não foram facilmente absorvidos pela sociedade local, muito ao contrário. Os testemunhos a isso referentes, textuais e iconográficos, são muito numerosos (SCHULTZ; WEST; MACLEAN, 
1999, p.17; MANNING; ROMERSTIEN, 2004, p.48-50).7

Tudo isto bem considerado, não nos deveria espantar que Lovecraft, que em certos trechos de seus escritos manifestou um verdadeiro horror pelos imigrantes e pela ideia de que eles viriam a se tornar os futuros estadunidenses, tivesse a pior das opiniões sobre as suas expressões religiosas; o que chama atenção aqui é justamente o fato de não haver um anti-catolicismo explícito em seus contos, do primitivismo papista não ser por ele assemelhado ao caráter "indescritivelmente ameaçador e horrível" das formas oníricas que a Gilman recordam "vívidos ídolos hindus e intrincados arabescos despertados numa espécie de ofídica imaginação" (LOVECRAFT, 2013, p.133). Assim sendo, já se pode anunciar aqui o argumento central de nosso trabalho: é justamente a ambiguidade de Lovecraft em relação ao catolicismo que é digna de interesse, não a sua eventual caricaturização das práticas desta religião - expediente que o colocava, não obstante seu ateísmo, no interior da sensibilidade religiosa residual comum da Nova Inglaterra de seu tempo.

Essa representação ambígua está bem presente no "Sonhos na Casa da Bruxa", por exemplo, na caracterização que se faz de Joe Mazurewicz, um dos inquilinos que morava no térreo da casa em que Gilman alugou um quarto, e que incomodava demasiado os seus ouvidos anormalmente aguçados pela febre com suas orações repetitivas. Esse consertador de teares contava a seu vizinho,

[...] longas e desconexas histórias sobre o fantasma da velha Keziah e a criatura peluda de presas afiadas [que a acompanhava], e dizia ter sido tão terrivelmente assombrado às vezes que somente

7 Para uma interessante e recente história geral do anti-catolicismo, ver STARK, 2016. 
seu crucifixo de prata - que lhe fora dado com este propósito pelo Pe. Iwanick, da Igreja de Santo Estanislau - Ihe trazia alívio. Agora orava porque o Sabbath das feiticeiras se aproximava. Era véspera da noite de Walpurgis, quando o mais negro mal do inferno vagava pela terra e todos os escravos de Satã reuniam-se para inomináveis atos e ritos. Era sempre um período muito ruim em Arkham, embora as boas pessoas da Miskatonic Avenue e das ruas Alta e de Saltonstall fingissem nada saber sobre isso. Haveria feitos maléficos - e uma criança ou duas provavelmente desapareceriam. Joe sabia dessas coisas porque sua avó, do velho continente, as tinha ouvido de sua avó. Era sábio o ato de fazer preces e rezar terços nessa época. Por três meses Keziah e Brown Jenkins não tinham sido vistos perto do quarto de Joe, nem perto do quarto de Paul Choynski, mas em qualquer outro lugar - e não era nada bom quando sumiam assim. Significava que tramavam algo (LOVECRAFT, 2013, p.136-137).

Em certa ocasião, enquanto retornava de uma de suas desvairadas caminhadas, nas quais se sentia sumamente atraído por um ponto localizado em algum lugar no céu, entre as estrelas, Gilman deparou-se à entrada do solar com Mazurewicz, "ansioso e relutante para cochichar-lhe uma nova superstição". O polonês contou que na noite anterior, ao voltar da comemoração do Dia dos Patriotas em Massachussets, vira na janela do quarto do estudante a fraca resplandecência violenta que, como todos em Arkham bem o sabiam, indicava que no interior do cômodo encontrava-se Keziah Mason e seu familiar. Não só Mazurewicz haviam visto aquela luz, mas, em outras ocasiões, Choynski e Dombrowski julgaram-na perceber escoando pelas rachaduras do desvão lacrado acima do 
quarto de Gilman. Todos concordaram em não falar sobre este assunto incômodo, mas Mazurewick dispôs-se a recomendar que Gilman tomasse para si um outro quarto "e pedisse um crucifixo a um bom padre, como o Pe. Iwanicki". Gilman sabia que o polonês deveria estar meio bêbado quando chegou da festa, mas a menção àquela luz o perturbou sobremaneira, pois era um elemento comum em seus sonhos "e pensar que uma segunda pessoa totalmente desperta era capaz de ver a onírica luminescência estava completamente fora do abrigo da sanidade. Ainda assim, de onde o camarada tirou essa ideia absurda?" (LOVECRAFT, 2013, p.14).

Mais adiante, conforme se tornavam mais graves as experiências de Gilman e borravam-se mais e mais as fronteiras entre sonho e vigília, ele veio a pedir ajuda de Frank Elwood, seu colega de universidade e inquilino da mesma mansão. Contou a este seus sonhos e medos, enquanto o chocava menos por suas palavras do que por sua aparência singularmente abatida e pelas anormais queimaduras de sol que o marcavam. Naquele momento, contudo, não havia muito que Elwood pudesse Ihe dizer. Ele não havia visto seu colega em qualquer um de seus passeios sonâmbulos, nem imaginava a proveniência da curiosa imagem que teria trazido consigo de um destes.

Tinha, porém, ouvido o franco-canadense que morava bem abaixo do quarto de Gilman conversando com Mazurewicz uma noite destas. Falava, um ao outro sobre quão fortemente temiam a chegada da Noite de Santa Walpurga, dentro de poucos dias; e trocavam compassivos comentários sobre o pobre e condenado cavalheiro... Desrochers, o sujeito que morava abaixo do quarto de Gilman, falara de passos 
noturnos, calçados e descalços, e da luz violeta que vira uma noite quando subira amedrontado para espiar pela fechadura de Gilman. Mas não tivera, afinal, o coração de espiar, disse a Mazurewicz, depois de vislumbrar a luz através das fendas ao redor da porta. Houvera sussurros, também - e quando começou a descrevê-los sua voz baixou a um tom inaudível. (LOVECRAFT, 2013, p.146)

Elwood não podia imaginar que tipo de coisa havia suscitado tais fofocas supersticiosas, mas supôs que elas se devessem tanto aos hábitos noturnos de seu colega quanto à proximidade da Noite de Walpurgis.

Que Gilman falava dormindo era incontestável, e obviamente foi por escutar pela fechadura que Desrochers teve a ilusória impressão de a luz violeta emanava [de seu quarto]. Aquelas pessoas simplórias eram rápidas em imaginar ter visto qualquer absurdo de que tivessem ouvido falar (LOVECRAFT, 2013, p.146).

Gilman, portanto, deveria ficar no quarto de Elwood, evitando dormir sozinho, e consultar um médico especialista no tipo de problema que apresentava assim que possível. O plano inicialmente foi muito bem sucedido, e nos dias que se seguiram Gilman gozou de uma imunidade quase completa a respeito das manifestações mórbidas que o vinham afligindo nos últimos tempos, e não mostrou, segundo seu novo colega de quarto, qualquer tendência a falar ou caminhar durante o sono.

O único elemento perturbador era a conversa entre os estrangeiros supersticiosos, cuja imaginação estava altamente entusiasmada. Mazurewicz sempre tentava fazê-lo aceitar um crucifixo, e 
finalmente Ihe impingiu um que, segundo ele, fora abençoado pelo bom Pe. Iwanicki. Desrochers também tinha algo a dizer - aliás, insistiu que passos cautelosos soavam do quarto agora vago acima dele durante a primeira e a segunda noite de ausência de Gilman. Paul Choynski pensou ter ouvido sons nos saguões e na escadaria à noite, e alegou que a sua porta teria sido levemente forçada, enquanto a Sra. Dombrowski jurou ter visto Brown Jenkins pela primeira vez desde o Dia de Todos os Santos. (LOVECRAFT, 2013, p.147)

Considerando, entretanto, que "tais ingênuos relatos não significavam quase nada", Gilman deliberadamente deixou de lado o crucifixo que Ihe deu Mazurewicz. Passou a percorrer com Elwood os museus locais no esforço de identificar a peça que havia aparecido em sua cama depois de um de seus sonhos mais estranhos, mas não teve sucesso neste intento. Passou a compartilhar com seu colega suas teorias a respeito dos vínculos entre matemática avançada, as antigas histórias de bruxaria e a presença sobrenatural que o incomodava em seu quarto, e em certa noite,

$$
\begin{aligned}
& \text { assim que Gilman e Elwood se recolheram, } \\
& \text { sonolentos demais para prosseguir com a } \\
& \text { discussão, ouviram Joe Mazurewicz cambalear } \\
& \text { para dentro de casa meio bêbado, e estremeceram } \\
& \text { ante o arrebatado desespero de suas lamuriosas } \\
& \text { preces (LOVECRAFT, 2013, p.148). }
\end{aligned}
$$

Naquela mesma noite, Gilman novamente viu a bruxa e seu familiar, assim como o terrível homem negro que eventualmente passara a acompanhá-los, e parece ter participado, impelido por forças malignas, do sequestro de um bebê para fins os mais funestos. Desperto em seu próprio quarto e cercado de numerosos indícios 
físicos da realidade de seu delírio, "quanto mais se lembrava de seu hediondo sonho, mais apavorado ficava, e somou-se ao seu desespero ouvir Joe Mazurewicz entoar tristonhos cânticos dois andares abaixo" (LOVECRAFT, 2013, p.150).

Mais tarde, ao ver no jornal a notícia do rapto de um pobre bebê filho de imigrantes em circunstâncias similares às que se lembrava, Gilman entregou-se a um desespero crescente, pois

Desta vez nenhum deles podia duvidar que algo terrivelmente sério se fechava ao seu redor. Entre quimeras de pesadelo e as realidades do mundo objetivo, cristalizava-se uma relação monstruosa e impensável, e somente espantosa vigilância poderia evitar desdobramentos ainda mais funestos. [...] Joe instava o jovem cavalheiro a usar seu crucifixo de corrente niquelada, e Gilman, fazendo a vontade do vizinho, pendurou-o no pescoço por dentro da camisa. (LOVECRAFT, 2013, p.51-52)

Na noite seguinte, Gilman viu-se novamente no espaço acima de seu quarto no sótão, em companhia da bruxa e de seu familiar. Participava contra sua vontade do ritual de sacrifício do bebê raptado. No momento em que Keziah empurrou a faca contra a criança, o estudante reagiu, deixou cair a tigela que deveria receber o sangue da criança e investiu contra a bruxa, desarmando-a. A superioridade do combate, contudo, logo inverteu-se, e Gilman viuse estrangulado por suas mãos dotadas de uma força muito maior do que aquela que aparentava ter em seu corpo decrépito.

Ele sentiu a corrente do reles crucifixo comprimir-se contra o seu pescoço e, em sua aflição se perguntou qual seria o efeito que a vista do objeto teria sobre a maligna criatura. Sua força era inteiramente 
sobre-humana, mas enquanto ela continuava a estrangulá-lo, ele conseguiu enfiar a mão na camisa e alcançou o símbolo de metal, partindo a corrente e puxando-o para fora. À vista do objeto a bruxa pareceu tomada de pânico, e seus punhos fraquejaram o bastante para dar a Gilman a chance de se libertar. Arrancou as férreas garras de seu pescoço e teria arrastado a megera até a borda do abismo se tais garras não tivessem recebido novo acesso de força e se fechado novamente. Desta vez decidiu responder na mesma moeda, e suas próprias mãos buscaram a garganta da criatura. Antes que ela notasse o que ele fazia, ele enrolara a corrente do crucifixo à volta do pescoço dela, e um instante depois apertara o bastante para sufocá-la. (LOVECRAFT, 2013, p.153)

Durante a agonia de Keziah, entretanto, Gilman foi atacado por Brown Jenkins com uma forte mordida no tornozelo. Com um chute poderoso, lançou longe o familiar, além da borda de um abismo, e o ouviu choramingando muito mais abaixo. Não sabia se tinha matado a bruxa, mas a deixou no chão enquanto a luminescência violeta que sempre a envolvia ia diminuindo progressivamente. Antes que ficasse às cegas, teve a infelicidade de constatar que, o que a velha não havia feito com o punhal, Brown Jenkins havia feito com suas garras e presas: a tigela antes caída no chão, agora aprumada e cheia do sangue do bebê raptado.

Em seu delirante sonho, Gilman ouviu o infernal cântico de ritmo inumano do Sabbath vindo de uma distância infinita, e soube que o homem negro devia estar lá. [...] Pouco antes de mergulhar [de volta para a sua própria dimensão], a luz roxa se apagou deixando-o em completa escuridão. A feiticeira - a velha Keziah - ou Nahab - aquilo 
deveria significar que estava morta. E mesclado ao distante cântico do Sabbath e às lamúrias de Brown Jenkins no abismo abaixo, teve a impressão de ouvir outro lamento ainda mais desvairado, vindo de profundezas desconhecidas. Joe Mazurewicz as orações contra o Caos Rastejante tornando-se agora um inexplicável clamor de triunfo - mundos de sarcástica realidade afetando os vórtices do sonho febril - lä! Shub Niggurath! A Cabra com mil filhotes... Acharam Gilman no chão do seu velho quarto no sótão angular muito antes de amanhecer, pois o terrível grito trouxera Desrochers, Choynski, Dombrowski e Mazurewicz imediatamente, e tinha até mesmo acordado Elwood, que dormia profundamente em sua poltrona. Estava vivo, com os olhos muito abertos, fixos, mas aparentemente inconsciente. Em sua garganta havia marcas de mãos assassinas, e no seu tornozelo esquerdo uma aflitiva mordida de rato. Sua roupa estava muito amarrotada e o crucifixo de Joe havia desaparecido. Elwood tremia, com medo até de imaginar que nova forma o sonambulismo de seu amigo teria tomado. Mazurewicz parecia meio atordoado por causa de um sinal que disse ter recebido em resposta às suas orações, e benzeu-se freneticamente quando um guinchar e choramingar de rato soou além da parede inclinada. (LOVECRAFT, 2013, p.154-155 Grifo no original)

Os elementos de ambiguidade deste trecho são numerosos. As constantes orações de Mazurewicz foram, afinal, eficazes ou não? Ora, deve-se considerar que a bruxa foi morta pelo estudante, mas o sacrifício esperado foi realizado. Mais ainda: a quem exatamente o polonês se dirigia em suas orações contra o Caos Rastejante? À Virgem e aos santos cuja devoção sua avó havia trazido consigo do velho continente e havia aprendido com a avó dela, à algo mais 
sinistro - a Cabra dos mil filhotes - escondido sob o verniz de uma experiência religiosa corriqueira, ou à alguma confusa mistura das duas coisas, determinada por sua credulidade, as constantes bebedeiras, talvez mais do que uma insinuação de insanidade? Qual a natureza e qual o significado do sinal que ele recebeu em atendimento às suas preces durante este clímax? De outra parte, pode-se considerar que estes fatores ambíguos são ainda ampliados pelo fato de que, na noite seguinte ao seu confronto com Keziah, Gilman morre quando uma grande e deformado ratazana cavou um túnel em seu tórax e comeu o seu coração. Diante disso,

Dombrowski, exasperado pelo fracasso de seu constante esforço de eliminar os ratos, pôs de lado qualquer escrúpulo relativo ao seu contrato de locação e em uma semana havia-se mudado com todos os seus antigos hóspedes para uma casa esquálida, porém menos antiga, na Walnut Street. Durante algum tempo, o pior de tudo foi fazer Joe Mazurewicz ficar quieto; pois o consertador de teares nunca estava sóbrio, nem parava de se lamentar e murmurar sobre essas coisas espectrais e terríveis. Parece que naquela horripilante última noite, Joe havia-se abaixado para examinar as pegadas de rato avermelhadas que iam do sofá de Gilman até o buraco na parede. Sobre o tapete eram muito indistintas, mas havia um pedaço de assoalho descoberto entre a borda do tapete e o rodapé. Ali Mazurewicz tinha achado algo monstruoso ou pensou ter achado, pois ninguém mais podia concordar com ele sobre a inegável estranheza das pegadas. As marcas no piso eram certamente muito diferentes das pegadas comuns de ratazana, mas nem mesmo Choynski e Desrochers quiseram admitir que pareciam marcas de quatro minúsculas mãos humanas. (LOVECRAFT, 2013, p.156) 
Certos críticos notaram com surpresa que Lovecraft tenha escrito que Keziah Mason pareceu tomada de pânico pela visão do crucifixo empunhado por Gilman e abençoado pelo Pe. Iwanicki, e tiveram especial dificuldade para explicar este trecho do conto. ${ }^{8}$ Alguns sustentaram que isso é um elemento de menor importância, mesmo ridículo, especialmente caso se considere que Lovecraft era ateu desde jovem; uma mera sobrevivência, talvez inconsciente, de estereótipos presentes em algumas estórias de terror mais antigas. Outros afirmaram que a bruxa ficou simplesmente surpresa ao ver que um objeto de metal afiado [sic] estava sendo empurrado em direção a seu rosto; enquanto um terceiro grupo aventa a possibilidade de que, com este pânico, Lovecraft estaria indicando (em possível denúncia) o quanto a velha havia sido psicologicamente danificada pelas torturas que os cristãos lhe infligiram no século XVII (PRICE, 1995, p.XII). De toda forma, a recepção do "Sonhos na Casa da Bruxa", único conto de Lovecraft onde a fé cristã - especificamente em sua versão católico romana - talvez tenha algum papel eficaz no combate contra as forças que ameaçam a humanidade, nunca foi boa; Steven J. Mariconda chamou-o de "o magnífico fracasso de Lovecraft" (1991, p.192), definição com a qual Joshi afirmou que "pode-se concordar incondicionalmente" (2014, p.362).

De modo muito evidente, "Sonhos na Casa da Bruxa" é a tentativa de modernizar o mito convencional da bruxaria através da ciência moderna, estratégia que antes já havia sido teorizada e empreendida

8 Meses antes da redação do "Sonhos na Casa da Bruxa", o Pe. Iwanicki havia sido duas vezes mencionado por Lovecraft em um dos esboços descartados de "A sombra em Innsmouth". Neste, o vigário da Igreja de São Estanislau de Arkham é lembrado como um religioso crédulo, ingênuo e supersticioso, mas também como alguém que poderia dizer muito a respeito do recente incêndio que (nesta versão do conto) destruiu por completo a vila pesqueira de Innsmouth (JOSHI \& SCHULTZ, 2011, p.128; LOVECRAFT, 1995). 
por Arthur Machen. ${ }^{9}$ Em seu preciso ensaio sobre o conto, Fritz Leiber destacou que se trata da mais cuidadosa elaboração de uma história de viagem pelo hiperespaço, pois nela: 1. as fundações racionais de tal viagem são explicitadas, 2. o hiperespaço é descrito, e 3. produz-se uma motivação para a viagem. Leiber observa que a ausência de qualquer instrumento mecânico para tais viagens é vital para a montagem do argumento do conto, pois do contrário seria impossível imaginar como uma bruxa do século XVII poderia têlas empreendido; de fato, Keziah simplesmente aplica matemática avançada e, ao imaginar a si mesma no hiperespaço, é capaz de atravessá-lo (LEIBER, 1966, p.171-173). Joshi considera que esta novela de escopo imaginativo "quase inconcebivelmente vasto" é arruinada porque teria Lovecraft nela recaído "em estereótipos (referentes a histórias de bruxas) e numa prosa excessivamente ornamentada que soa quase como uma paródia de seu próprio estilo" (2014, p.362). Parece-me, contudo, que a rejeição de Joshi ao "Sonhos na Casa da Bruxa" tem algo a ver com a representação ambígua que, em seu interior, tem a devoção religiosa como uma possível proteção contra a ação da velha Keziah. Segundo este analista - que para este juízo apoia-se também em David E. Schultz (1991)

[...] O que Lovecraft estava realmente fazendo
era criar uma antimitologia. Qual é a ideia das
religiões e das mitologias? É justificar os caminhos

9 Em 1894, em uma missiva a propósito de seu $O$ grande deus Pã, esse autor galês a escreveu a John Lane, da editora Bodley Head, que lhe havia proposto alterações no enredo e a supressão do primeiro capítulo da novela, que: "[...] Se estivesse escrevendo na Idade Média, eu não precisaria de qualquer base científica, porque naquele tempo o sobrenatural per se era totalmente crível. Hoje em dia, o sobrenatural é totalmente incrivel; para acreditar, temos de vincular nossos assombros a alguma base, ou método, científico ou pseudocientífico. Assim, não acreditamos em fantasmas, mas em telepatia, não em bruxaria, mas em hipnotismo. Se o Sr. Stevenson tivesse escrito sua notável obra-prima por volta de 1590-1650, Dr. Jekyll teria feito um pacto com o diabo. Em 1886, Dr. Jekyll encomenda algumas drogas raras numa farmácia de Bond Street" (ARANTES, 2002, p.170 - Grifos no original). 
de Deus ao homem. Os seres humanos sempre se consideraram no centro do universo; eles povoaram o universo com deuses das mais variadas naturezas e capacidades com meio de explicar os fenômenos naturais, de justificar sua própria existência, de se proteger da terrível perspectiva de ser esquecido após a morte. Cada religião e mitologia estabeleceu algumas conexões vitais entre deuses e seres humanos, e é exatamente essa conexão que Lovecraft quer subverter com sua pseudo-mitologia. (JOSHI, 2014, p.282-283) ${ }^{10}$

Isto de fato se verifica em praticamente todos os contos de Lovecraft, mas em "Sonhos da Casa da Bruxa" há talvez alguns elementos que fazem com que esse juízo a respeito de Lovecraft precise ser ligeiramente matizado. Talvez este seja um dos motivos de sua rejeição estética tão veemente por Joshi e outros autores que têm a mesma avaliação que ele a respeito do que era a filosofia implícita nas estórias de Lovecraft. Cabe observar, por fim, que esta rejeição não é necessária, nem unânime: o crítico e novelista Michel Houllebecq (2005) situa "Sonhos da Casa da Bruxa" entre os oito melhores e mais fundamentais dos textos de Lovecraft referentes ao mito de Cthulhu, colocando-o ao lado de estórias de prestígio mais comumente reconhecido como "O chamado de Cthulhu" (1926/1928), "A cor vinda do espaço" (1927), "O Horror de Dunwich" (1928/1929), "Um sussurro na escuridão" (1930/1931), "Nas montanhas da loucura" (1931/1936), "A sombra em Innsmouth" (1931/1936) e "A sombra vinda do tempo" (1934/1936).

10 A expressão justificar os caminhos de Deus ao homem foi extraída do Paraíso Perdido, de John Milton (1:26). 


\section{UMA VIGÍlIA DE LUZ PARA SALVAR A CIDADE DO PESADELO QUE ESPREITA: “O ASSOMBRO NAS TREVAS” (1935/1936)}

"O assombro nas trevas" foi composto por Lovecraft em circunstâncias bastante diversas das de "Ar frio" e de "Sonhos na Casa da Bruxa". Esse conto veio à luz como último produto do derradeiro período criativo deste autor, falecido antes dos cinquenta anos de idade. Ele foi inteiramente produzido em Providence entre 5 e 9 de novembro de 1935, quase como capricho. Na primavera deste ano, Robert Bloch escreveu a estória "O vampiro vindo das estrelas", na qual um dos personagens, que não chega a ser nomeado, mas que foi claramente inspirado em Lovecraft acaba sendo morto entre gargalhadas histéricas e lufadas de vento sobrenatural, por uma monstruosidade invisível invocada por descuido das profundezas do espaço. Após ela ter sido publicada na Weird Tales de setembro, um leitor escreveu à revista elogiando-a efusivamente e, percebendo a referência feita por Bloch, sugeriu que Lovecraft respondesse à homenagem e dedicasse ao colega uma narrativa em termos similares (JOSHI, 2014, p.418). Encantado com o conto e com a sugestão, Lovecraft compôs "O assombro nas trevas", cujo enredo trata de certo Robert Blake que acaba como um cadáver "enrijecido [...] sentado junto à escrivaninha, em frente à janela [...] os olhos fixos, vidrados, e as marcas de horripilante e convulsivo pavor [...] [na] fisionomia contorcida" (LOVECRAFT, 2012, p.94).

A gênese prosaica e mesmo divertida da estória, entretanto, não deve nos enganar - de acordo com Joshi, trata-se de "um dos contos mais fortes de Lovecraft" (2014, p.418). Ele trata de um jovem escritor de ficção fantástica que chega a Providence para lá trabalhar por algum tempo, mas que acaba fascinado pelo perfil 
de uma igreja em ruínas abandonada, construção cuja imagem longínqua divisa da janela de seu escritório. Depois de meses observando "a severa estrutura distante com crescente interesse", estimulando sua imaginação que insinuava que "uma aura vaga e singular de sordidez" pairava sobre o local, e, com ajuda de um binóculo, mostrando-a a vários de seus conhecidos e constatando que "nenhum deles [...] tinha a mais remota ideia sobre o que a igreja era ou havia sido", "logo antes do Walpurgis à sombra dos éons, Blake fez sua primeira incursão rumo ao desconhecido". Avançando pelas intermináveis "ruas do centro e pelos ermos quarteirões decrépitos mais além", pela "avenida ascendente com a escadaria de degraus gastos pelo século, os pórticos dóricos abaulados e as cúpulas de vidros baços que, segundo imaginava, conduziriam ao inalcançável mundo além da névoa que de longa data conhecia", pelos "rostos estranhos e sombrios da multidão de passantes e os símbolos estrangeiros acima de curiosas lojas em construções marrons desgastadas pelo tempo", chegou, afinal, ao coração de Federal Hill, o bairro italiano, um emaranhado de "intrincados labirintos de agourentas ruelas marrons que conduziam eternamente ao Sul". Perguntou a um lojista pela construção que procurava e obteve em resposta apenas um sorriso e um meneio de cabeça; algo perdido, fez novas perguntas a outro comerciante, "e nessa segunda tentativa ele poderia jurar que a alegação de ignorância era falsa”, afinal, "[...] O rosto bronzeado do homem tinha uma expressão de medo que ele tentava ocultar, e Blake o viu fazer um curioso gesto com a mão direita" (LOVECRAFT, 2012, p.72-74). Dando quase que por acaso com a praça onde se erguia o enorme vulto de pedra, viu-se diante da igreja deserta, que 
[...] apresentava sinais de profunda decrepitude. Alguns dos altos contrafortes de pedra haviam desabado, e muitos remates frágeis jaziam meio perdidos entre as ervas daninhas e gramas marrons negligenciadas. [...] A desolação e a decadência estendiam-se como uma mortalha sobre o lugar, e nos beirais vazios de pássaros e nas muralhas negras, despidas de hera, Blake sentiu um toque sinistro que não seria capaz de definir. (LOVECRAFT, 2012, p.74-75)

Na praça onde se erguia a sinistra construção havia pouquíssimas pessoas, mas passou um policial, ao qual se aproximou com perguntas a respeito da igreja.

O homem era um irlandês robusto, e a Blake pareceu estranho que não fizesse muito mais do que se persignar e balbuciar coisas sobre as pessoas jamais falarem a respeito daquela construção. Quando Blake o pressionou, o policial irlandês disse às pressas que o padre italiano advertia a todos contra a igreja, jurando que outrora um mal monstruoso havia habitado o lugar e lá deixado sua marca. O próprio irlandês ouvira histórias lúgubres contadas à meia voz por seu pai, que relembrava certos sons e rumores da infância. Nos velhos tempos uma seita vil reunia-se lá - uma seita clandestina que invocava coisas terríveis dos ignotos abismos da noite. Fora preciso um excelente padre para exorcizar o que então surgiu, embora algumas pessoas dissessem que apenas a luz poderia bani-lo. Se o padre O'Malley estivesse vivo ele teria muitas histórias para contar. Mas naquele ponto não havia mais nada a fazer, salvo esquecer a igreja. Ela já não prejudicava ninguém, e seus proprietários estavam mortos ou vivendo em lugares distantes. [...] Um dia a cidade tomaria a frente e assumiria a posse da construção devido 
à inexistência de herdeiros, mas essa medida não resultaria em nada de bom. O melhor seria deixá-la ruir com o passar dos anos e não mexer com coisas que devem descansar para sempre em abismos sombrios. (LOVECRAFT, 2012, p.75-76)

Com a imaginação ainda mais estimulada por essa estranha conversa, Blake arruma um jeito de entrar no interior da antiga construção, e lá, além de volumes negros e proibidos "sobre as quais a maioria das pessoas em sã consciência jamais ouviu falar, ou então ouviu falar apenas em sussurros furtivos e temerosos", tais como "uma versão latina do execrando Necromonicon [...] e o infernal De Vermis Mysteriis do velho Ludvig Prinn", encontra também um curioso e desconhecido objeto - uma caixa de metal contendo uma curiosa gema ou minério - bem como o esqueleto de um velho repórter, cujas anotações remanescentes ele se apressa em ler. Essas linhas crípticas tratam da malvista Igreja da Sabedoria Estrelada, de um Trapezoedro Reluzente e de um Assombro nas Trevas, uma monstruosidade guardiã de segredos dos céus e de outros mundos, que é saciada com sacrifícios de sangue humano e incapaz de existir na luz. Subitamente assustado, Blake fecha a tampa da caixa que contém aquilo que deduz ser o citado Trapezoedro e deixa o lugar; este ato impensado, sem querer, liberta um monstro confinado no sino da igreja, e essa criatura - uma das manifestações de Nyarlathotep - passa a procurar uma maneira de fundir sua mente com a de seu libertador, eventualmente a consumindo no processo. Então, espraiando-se desde a velha construção, um novo terror passa a pairar sobre Federal Hill, e

Aos sussurros os italianos comentavam estranhas movimentações e estrondos e arranhões vindos 
do sombrio coruchéu sem janelas e pediam aos padres que banissem a entidade que assombrava seus sonhos. Alguma coisa, diziam, estava de guarda dia e noite na porta, esperando um momento escuro o suficiente para se aventurar mais longe. Os jornais [da cidade] faziam menção às antigas superstições locais, mas não esclareciam muita coisa a respeito dos motivos para tamanho horror. (LOVECRAFT, 2012, p.86)

Em uma manhã, entretanto, uma notícia que de fato não passava "de uma variante do tema algo jocoso da inquietude em Federal Hill", acrescentou uma nota "terrível ao extremo" aos já grandes receios de Blake. Durante a noite anterior, uma tempestade comprometera o sistema de iluminação da cidade, deixando-a no escuro por uma hora inteira, e nesse período os italianos do bairro

[...] haviam quase enlouquecido de pavor. Os que moravam próximo à temível igreja juravam que a coisa no coruchéu aproveitara-se da ausência de iluminação pública para descer até a nave da igreja, cambaleando e debatendo-se de maneira viscosa, absolutamente horripilante. Após algum tempo, subiu cambaleante até a torre, onde se ouviram sons de vidro quebrando. Aquele ser poderia ir até onde as trevas alcançassem, mas a luz sempre o poria em fuga. Quando a corrente elétrica voltou houve uma terrível comoção na torre, pois até mesmo a tênue iluminação que filtrava pelas janelas fuliginosas e protegidas por adufas era demais para a coisa. [...] Durante aquela hora no escuro, sob a chuva, multidões reuniram suas preces ao redor da igreja com velas acesas protegidas por papéis dobrados e guarda-chuvas uma vigília de luz para salvar a cidade do pesadelo que espreita nas trevas. Segundo os que estavam próximos à igreja, em um dado momento a porta 
externa chacoalhou de maneira horripilante. (LOVECRAFT, 2012, p.87)

Conforme segue o mês chuvoso, "o diário de Blake registra uma maré crescente de horror insidioso e apreensão nervosa". Seus apontamentos concentram-se mais e mais nos seus pesadelos, que parecem ser o veículo do fortalecimento de uma ligação profana entre ele e a coisa que libertou. Impulsos sonâmbulos e devaneios monomaníacos o impelem em direção à igreja, e ele toma medidas cada vez mais severas para impedir-se de seguir até lá; de qualquer forma, passa boa parte de seu tempo "absorto junto à escrivaninha, observando pela janela oeste o longínquo coruchéu proeminente além da fumaça citadina" (LOVECRAFT, 2012, p.89). No começo de agosto, uma grande tempestade precipita o seu fim. Depois de pouco mais de duas horas de chuva torrencial, com raios que caíam sem parar, as luzes de toda a cidade apagaram-se devido a uma falha elétrica geral. Em Federal Hill, diante da velha igreja, estavam reunidos observadores tão ansiosos quanto Blake:

[...] grupos de homens encharcados desfilavam pela praça e pelas ruelas em torno da igreja com velas protegidas por guarda-chuvas, lanternas elétricas, lampiões a óleo, crucifixos e todo tipo de amuletos obscuros comuns ao sul da Itália. Eles abençoavam cada novo relâmpago e faziam gestos crípticos de temor com a mão direita quando algo na tempestade fez com que os relâmpagos diminuíssem e por fim cessassem. Um vento repentino apagou a maioria das velas, de modo que a cena ficou envolta em trevas ameaçadoras. Alguém chamou o padre Merluzzo, da Igreja do Espírito Santo, que se apressou até a fatídica praça a fim de pronunciar quaisquer sílabas de ajuda que 
pudesse. Quanto aos incansáveis e curiosos sons no interior da torre negra não podia haver a menor dúvida. (LOVECRAFT, 2012, p.92)

Na escuridão, começaram a aumentar os desordenados sons no interior da torre, que se avolumavam à medida que tornavamse ainda piores os odores estranhos e repulsivos que vinham emanando do interior do edifício. Seguiram-se sons de madeira sendo despedaçada e foi ao chão uma parte da grande janela a leste da igreja. Um miasma insuportável fez-se sentir desde o alto da torre quase invisível na escuridão, provocando sufocamentos e náuseas entre os observadores e quase lançando ao solo aqueles que estavam mais próximos. $\mathrm{O}$ ar tremeu com a vibração similar à que seria produzida por um ruflar de grandes asas, e um vento repentino que superava em intensidade todas as rajadas anteriores atirou para longe os chapéus e guarda-chuvas da multidão reunida em vigília. Nada pôde ser visto com clareza, mas alguns espectadores que estavam olhando para cima imaginaram ver uma macha de negrura ainda mais profunda do que a do céu sem estrelas espalharse rapidíssima da torre em direção a leste. Após isso, o grupo, ferido de pavor e desconforto, mal sabia o que fazer, ou mesmo se devia fazer qualquer coisa.

Sem saber o que tinha acontecido, mantiveram a vigília; e passado um instante uniram-se em uma prece coletiva quando o clarão súbito de um relâmpago tardio, seguido por um estrondo ensurdecedor, rasgou os céus chuvosos. Meia hora depois a chuva parou, e passados mais quinze minutos a iluminação pública voltou a funcionar, mandando os vigilantes encharcados e exaustos aliviados para casa. (LOVECRAFT, 2012, p.93) 
Acontecimentos assombrosos foram verificados também no restante da cidade, e no começo da noite seguinte a casa de Blake foi arrombada por um policial e ele foi encontrado morto.

Alguns dos detalhes do enredo de "O assombro nas trevas" foram diretamente extraídos de "A aranha", conto de Hanns Heinz Ewers que Lovecraft havia lido em uma coletânea organizada por Dashiel Hammett, publicada em 1931. Essa estória trata de um homem que fica fascinado por uma estranha mulher que pode observar de sua janela em um prédio de frente para o seu, até que ele finalmente perde o controle de sua personalidade em favor da obsessão por ela. Um número considerável de lugares descritos no conto dedicado a Bloch é baseado em locais verdadeiros de Providence. A vista do escritório de Blake não é outra coisa senão uma descrição precisa do que Lovecraft via de seu próprio escritório na casa em que residiu na College Street. A abandonada Igreja da Sabedoria Estrelada, que figura de forma tão proeminente na narrativa, é largamente decalcada da Igreja Católica de São João Batista na Atwell's Avenue, em Federal Hill, que acabou demolida em 1992. Na década de 1930, tratava-se do principal templo católico de Providence, e, nessa condição, era uma importante referência comunitária. De acordo com Joshi, a descrição do interior e do campanário da igreja é bastante precisa. O pináculo foi destruído por um raio no fim de junho de 1935, enquanto Lovecraft estava fora da cidade, em viagem para Barlow, na Flórida, e as autoridades eclesiásticas decidiram, ao invés de reconstruí-lo, colocar em seu lugar uma cobertura cônica sobre a torre de tijolos, incidente que sem dúvida colocou para trabalhar a imaginação do autor (JOSHI, 2014, p.418-419). 
A Igreja do Espírito Santo foi a primeira paróquia de língua italiana em Providence, criada em 1899 para atender um dos cinco grandes grupos de católicos lá residentes - os outros eram os irlandeses (a grande maioria) os franco-canadenses, os poloneses e os portugueses. Como outras paróquias étnicas criadas na região pelo bispo Matthew Harkins para atender aos novos conjuntos de fiéis que a imigração colocou sob seu pastoreio, essa comunidade também foi entregue aos cuidados dos padres da Congregação dos Missionários, conhecidos como carlistas ou scalabrinianos, aprovada pelo Vaticano em 1887 e dedicada à catequese e assistência dos migrantes. Em 1905, mais da metade da população de Providence era católica romana, e Rhode Island foi o primeiro estado dos EUA a ter uma maioria não-protestante. Alguns líderes cívicos regionais, para quem o protestantismo era um componente essencial da identidade americana, não cessaram de lembrar que Providence, uma das mais antigas cidades do país, havia sido fundada como um refúgio para os protestantes, e procuraram excluir sistematicamente os imigrantes católicos da vida pública da cidade, procurando inclusive restringir o seu direito de voto. Foi através das paróquias e das associações étnicas - incluindo sindicatos - a elas associadas que os imigrantes conseguiram conquistar um espaço de atuação política desde a década de 1880 até a de 1930 (STERNE, 2003). Tal movimentação não deixou indiferentes os autóctones, ainda mais se criativos e de escrita bem dotada como Lovecraft, sujeito que queria "simplesmente a familiaridade - a familiaridade do senso comum na Providence racial e culturalmente homogênea que ele experimentara na juventude", necessariamente contraposta à Providence cada vez mais urbana e racialmente heterogênea de sua maturidade (JOSHI, 2014, p.410). 
Talvez nas multidões de italianos reunidos em vigília - afinal inútil, mas de toda forma corajosa - ao redor da Igreja da Sabedoria Estrelada no coração de Federal Hill, possamos perceber um eco da movimentação pública dos imigrantes católicos em Providence ao tempo da escrita de "O assombro nas trevas".

\section{AMBIGUIDADES DO CATOLICISMO NO GÓTICO AMERICANO}

Os três contos que passamos em revista reiteram uma série de clichês lovecraftianos, não apenas destacados pela crítica especializada como bem reconhecidos pelo público em geral. Gostaria de chamar a atenção para dois deles. Em primeiro lugar, figura aí o seu acentuado racismo, manifestação de um temor quase supersticioso diante das levas de imigrantes que chegam ao território norte-americano durante o século XIX e primeira metade do século $X X$. Esse racismo, muito discutido pela crítica e fundado antes do mais no seu orgulho aristocrático, inversamente proporcional ao seu sucesso em vida e traduzido em uma das muitas formas de auto-exaltação da superioridade anglo-saxã verificadas na história cultural dos EUA, adquiriu lastro e refinamento tanto com as assustadoras experiências que Lovecraft fez na cosmopolita Nova lorque e na Providence de sua maturidade, quanto com sua leitura dos antropólogos e teóricos racistas do século XIX. Os juízos sobre o racismo de Lovecraft são bastante distintos: enquanto Bennett Lovett-Graff (1997) acreditou ver nisto um comprometimento consciente do autor com as teorias neodarwinistas e eugenistas em voga na primeira metade do século $X X$, Joshi tentou minimizar sua importância afirmando que "o racismo era para ele uma defesa contra a necessidade de reconhecer que seu ideal de um 
país puramente anglo-saxão não tinha mais qualquer relevância e não poderia ser recuperado" (2014, p.410). Em um ensaio agora célebre, Bruce Lord (2004) sustenta que o racismo de Lovecraft é justamente um elemento-chave para a compreensão do seu trabalho e do mundo que ele criou, enquanto mais uma vez Joshi, em polêmica recente, sustentou que o racismo de Lovecraft não era extraordinário para os padrões norte-americanos de sua época, e só tem sido enfatizado pela crítica recente por causa da hegemonia do politicamente correto nos estudos literários e das calúnias grosseiras e tendenciosas propagadas contra este autor por um pequeno, mas barulhento número de ativistas a quem ele desagrada (FLOOD, 2015).

Em segundo lugar, sua completa rejeição aos méritos da religião institucionalizada de modo geral, e sua dura linha crítica ao cristianismo em particular - de forma especial ao cristianismo, de matriz mais puritana, que considerava desprovido de quaisquer encantos ou méritos estéticos. Em “A chave de prata” (1926/1929), estória na qual Lovecraft, através de Randolph Carter, seu mais explícito alter-ego, apresenta a sua filosofia social, estética e ética de forma mais explícita e consistente (JOSHI, 2014, p.285), sustenta-se a crítica tanto à religião tradicional quanto ao materialismo vulgar pelo qual alguns haviam-na substituído:

Nos primeiros dias de seu cativeiro, ele havia se voltado à dócil fé religiosa valorizada aos seus olhos pela ingênua devoção de seus pais, pois dela se estendiam avenidas místicas que pareciam prometer escape da vida. Somente sob um exame mais minucioso ele reparou na escassez de fantasia e beleza, na trivialidade insípida e 
prosaica, na gravidade solene e nas grotescas alegações de verdade sólida que reinavam enfadonha e inapelavelmente sobre a maioria de seus professores; e sentiu plenamente a inaptidão com que ela buscava manter vivos como fatos literais os medos exacerbados e suposições de uma raça primitiva confrontada com o desconhecido. Carter se aborrecia ao ver com que solenidade as pessoas tentavam construir realidades terrenas a partir de velhos mitos que cada passo de sua alardeada ciência refutava, e essa seriedade fora de lugar eliminava a atração que ele poderia ter sentido pelos antigos credos, caso eles tivessem se contentado em oferecer os ritos sonoros e as vazões emocionais em sua verdadeira aparência de fantasia etérea. Mas quando ele começou a estudar os que haviam se despojado dos velhos mitos, achou-os ainda mais repulsivos do que aqueles que não haviam. [...] Via que a maior parte deles, assim como o clero que repudiavam, não conseguia escapar da ilusão de que a vida tem um significado separado daquele que os sonhos dos homens nela introduzem; e não podia distinguir a noção crua de ética e dever daquelas ligadas à beleza, mesmo quando a natureza ululava sua inconsciência e imoralidade impessoal à luz das descobertas científicas daqueles homens. (LOVECRAFT, 2012/2, p.129-130)

Em suas conhecidas análises da vida e da obra de Lovecraft, Joshi enfatiza bastante essa característica do autor, fazendo de sua Confissão de descrença, texto de 1922, um documento fundador para o entendimento de sua trajetória e produção intelectual (LOVECRAFT, 2010, p.5-10). Para compreender esta ênfase, não se pode deixar de lado o fato de que Joshi, além de crítico literário e editor das obras de Lovecraft, é também um militante do novo 
ateísmo contemporâneo, desde 2011 é editor-chefe da The American Rationalist, revista de grande circulação que pretende oferecer ao público uma alternativa às superstições religiosas, e um pensador que encontrou no ficcionista de Providence o esboço de um pensamento ético que considerou não de todo descartável. De fato, considerável parte das análises de Joshi a respeito de Lovecraft têm sido desenvolvidas em diálogo e em atrito com as reflexões a respeito deste autor feitas por Robert M. Price, teólogo e pastor batista, ainda que não exatamente ortodoxo, pois chegou a descrever-se como um cristão ateu e está diretamente envolvido no campo daqueles estudos edificados em torno do ideal da desconstrução histórica da figura de Jesus Cristo. Se o background religioso de Price dá a ele material para enxergar os numerosos temas iniciáticos e mesmo gnósticos que estão presentes de modo mais ou menos estrutural na obra de Lovecraft, o comprometimento de Joshi, por outro lado, conduz talvez a uma ênfase muito bidimensional do ateísmo lovecraftiano, fazendo ver em suas estórias a mesma rejeição global da religião que o autor faz presente em sua vida pessoal e em seus ensaios especificamente dedicados ao tema.

Isto considerado, reitere-se que o que chama a atenção em "Ar frio", "Sonhos na Casa da Bruxa" e em "O assombro das trevas" não é a caracterização negativa que Lovecraft aí faz do catolicismo, essa religião de imigrantes que se estabelecem nos EUA vindos de paragens que ele considera tão primitivas, mas, ao contrário, justamente o fato de esta caracterização não ser ainda mais ou completamente negativa. Nos espanhóis da mansão tornada cortiço e administrada pela Sra. Herrero, nos poloneses vizinhos de Walter 
Gilman (e, de modo muito especial, em Joe Mazurewicz), e nos italianos de Federal Hill, literalmente cercando a temível Igreja da Sabedoria Estrelada com suas velas e orações, não há colaboração com o mal cósmico, como acontece com outros grupos étnicos nos contos de Lovecraft - como está explícito de modo paradigmático em "O chamado de Cthulhu" -, mas mesmo uma resistência a esse mal. Resistência fadada à impotência, pois, na perspectiva de Lovecraft, de fato pouco ou nada são os esforços e crenças humanos diante das monstruosidades muito mais antigas e muito mais vastas do que a humanidade, mas ainda assim resistência. Diante desta constatação, a questão da representação do catolicismo na obra lovecraftiana torna-se subitamente mais profunda e matizada, exigindo considerações mais detalhadas do que aquelas simplesmente derivadas de uma tomada de posição no âmbito do debate Joshi-Price a respeito do papel ou não da religião na obra de Lovecraft. Daí termos procurado investir em uma abordagem mais detalhista, que parte do micro para o macroscópico, evitando as transições muito precipitadas; caminho, entretanto, como já indicado, de fato muito pouco original, pois largamente baseado no trabalho de lan Almond sobre a presença de temas sufis nas estórias de Lovecraft, fundada antes do mais em uma complexa e ambígua relação deste autor com o material religioso islâmico.

Se tomarmos Lovecraft como um leitor, um continuador e um revivalista da tradição gótica, que Ihe insufla um ânimo peculiar ao continuar sua extensão rumo a novos espaços e temas no âmbito de um pessimismo cosmicista (ALMEIDA, 2008), a questão da representação do catolicismo nestes seus três contos que se destacou torna-se ainda mais interessante. Entre outras coisas, o 
romance gótico surgiu e lançou fortes raízes no ambiente criado pela propaganda anticatólica nos países reformados do Norte da Europa, supondo desde os seus primeiros exemplares uma representação hierarquizada que situa o temível nos tempos (a Idade Média), espaços (a Espanha, a Itália, a Europa Oriental) e instituições (o castelo feudal, o mosteiro, a inquisição) associados no imaginário moderno à Igreja Romana. De fato, o emprego de uma série de estereótipos anticatólicos na literatura popular de língua inglesa, em um panorama tão amplo que vai de obras evangelísticas a pornográficas, estereótipos que vão desde a reiteração do tema medieval do monge devasso às ilusões contemporâneas a respeito de uma conspiração mundial jesuítica, teve uma profunda influência no desenho temático da moderna literatura de terror; para constatá-lo, basta que nos lembremos d'O Monge (1796), de Matthew Lewis, d'O Italiano (1797) de Ann Radcliffe, do Melmoth (1820) de Charles Maturin, e de "O poço e o pêndulo" (1842) de Allan Poe (SNODGRASS, 2005, p.11-12). Indo ao encontro disto, pode-se mencionar a valiosa, ainda que agora já algo antiquada, pesquisa de Victor Sage (1988) sobre como a teologia e devoção protestantes forneceram o campo de experiências e o horizonte de expectativas que conformaram a retórica, determinaram a forma e informaram a psicologia da literatura de horror, inclusive em sua simultânea repulsa e fascínio por tudo aquilo que ficou associado nos imaginários norte-europeu e norte-americano ao catolicismo romano. Justamente por esta via analítica, chega-se à consideração daquilo que Diane Hoeveler (2014) chamou de a ideologia gótica, ou seja, da mais ou menos intencional perpetuação e acentuação na literatura de terror dos estereótipos anticatólicos como uma 
forma de construir um outro repugnante contra o qual as classes médias e baixas de língua inglesa e matriz religiosa protestante pudessem se definir como um corpo distinto e claramente superior, dentro de um projeto mais vasto de modernização e secularização do mundo ocidental.

Tal traço constitutivo desse tipo de literatura, entretanto, desenvolveu-se de modo muito particular nos EUA, onde a ele se somou na segunda metade do século XIX e na primeira do XX a forte e muito interessada identificação do católico com a figura do imigrante irlandês, polonês ou mediterrânico, esse outro tido como primitivo e supersticioso. Antes ou em paralelo a essa identificação, entretanto, já estava bem estabelecida uma ambiguidade constitutiva no tratamento dado ao catolicismo na literatura de ficção norte-americana (FRANCHOT, 1994). Se o país é um grande polo de produção e exportação deste tipo de material, pelo mesmo desde o ligeiro Seis meses em um convento (1835), de Rebecca Reed, e o pretensamente erudito A história do romanismo (1845), do Rev. John Dowling, livros que tiveram efeitos muito relevantes, dramáticos até, no relacionamento intereclesial nos EUA, alguns tradicionalistas norte-americanos expuseram de forma bastante relevante os sentimentos contraditórios que possuíam em relação à Igreja Romana. Foi o caso do próprio Lovecraft, que em carta escrita a Frank Belknap Long em abril de 1931, destacou a superioridade do paganismo ariano sobre a farsa semítica do cristianismo - um tema claramente nietzschiano - e ressaltou o quanto considerava o puritanismo da Nova Inglaterra colonial, que desprezava em suas crenças e sua (falta) de sensibilidade estética, mas ao qual se considerava ligado por laços consanguíneos em seu 
ethos, como a mais honesta das formas de cristianismo; sem deixar de escrever, contudo, que considerava o papismo como um sistema nem inconsistente, nem hipócrita, mas que, no seu procedimento de supostamente esvaziar a fé cristã de seus conteúdos éticos em favor da constituição de um aparato hierárquico e estético, conseguiu integrar certos povos pela religião de maneira bastante eficaz (LOVECRAFT, 2010, p.129-144).

Se parece mesmo fato que as representações de autores que Lovecraft admirou como William Beckford, Thomas Moore e Edgard Allan Poe sobre o Islã e o oriente não influíram na forma como estes passaram a figuras em suas estórias (ALMOND, 2015, p.78), parece-me, por outro lado, que as fugazes, mas significativas imagens do catolicismo constantes em "Ar frio", "Sonhos na Casa da Bruxa" e "O assombro nas trevas", assim como o constante na missiva a Long, devem menos a quaisquer experiências de vida ou posições ideológicas de Lovecraft do que a influência que sobre ele exerceu um autor sobre o qual também pesava o ethos puritano e a relação ambígua que esse nutria com o catolicismo romano: Nathaniel Hawthorne (JOSHI \& SCHULTZ, 2001, p.107; BURLESON, 1981). De modo particular, creio que podemos nos remeter à leitura que Lovecraft fez d'O fauno de mármore, o romance italiano de Hawthorne, publicado simultaneamente na América e na Europa em 1860, volume no qual trata bastante extensamente da questão do catolicismo romano.

Abordar o enredo deste livro apenas superficialmente simples nos colocaria aqui ainda mais para além do escopo deste texto já extenso. Basta observar que volume foi escrito em 1858, ano que Hawthorne e sua esposa Sophia Peabody passaram na Itália, 
essencialmente atuando como turistas; sua inspiração direta, segundo o próprio autor, veio da observação da escultura do Fauno de Paxíteles, vista no Palazzo Nuovo do Museu Capitolino de Roma. A respeito dele, Lovecraft escreve em $O$ horror sobrenatural na literatura que, tendo seu entrecho

[...] ambientado numa villa italiana com fama de mal-assombrada, um fundo lôbrego de genuíno mistério e fantasia palpita um passo além da visão do leitor comum; e laivos de sangue fabuloso em veias mortais insinuam-se no curso de um romance que não pode impedir-se de ser interessante apesar da persistente obsessão de uma alegoria moral, propaganda antipapista e um moralismo puritano que levou D. H. Lawrence a expressar o impulso de tratar o autor de um modo extremamente indecoroso. (1987, p.57-58)

Ligado ao mesmo ethos puritano que conforma a obra de Hawthorne e faz com que ele se aproxime de modo ambíguo do catolicismo romano (GRAHAM, 1999, cap. 2; VOIGT, 1946), mas nada preocupado com a polêmica religiosa e conscientemente evitando as alegorias morais, Lovecraft realiza uma leitura muito original dos estereótipos referentes aos católicos presentes na cultura norteamericana de seu tempo, e curiosamente chega em seus contos a uma representação do catolicismo similar àquela encontrada n'O fauno de mármore. Em determinado momento desta estória, o narrador emite a opinião de que

Roma tem, para os necessitados, certas espécies de consolação mais à mão do que qualquer outro lugar sob o céu [...] uma fé que tão maravilhosamente se adapta a cada necessidade humana. Não que possa satisfazer, de fato, as 
súplicas do coração, mas pode pelo menos às vezes auxiliar a alma para uma satisfação mais elevada do que a que a fé contém em si mesma. Fornece uma infinidade de formas exteriores nas quais o espírito pode se acomodar e manifestarse. Possui muitas vidraças pintadas através das quais a luz celeste, de outro modo imperceptível, pode tornar-se gloriosamente visível por meio de imagens de beleza e de esplendor. Nenhum desejo ou fraqueza humana existe para a qual o catolicismo não tenha um remédio correspondente. Possui cordiais em abundância, decerto, e sedativos em inexaurível variedade, que talvez tenham sido medicamentos genuínos, embora estejam agora um pouco piores por estarem há muito guardados. Fazendo-Ihe justiça, o catolicismo é um verdadeiro milagre de adequabilidade aos seus próprios fins, muitos dos quais parecem ser admiráveis, a tal ponto que é difícil imaginá-lo como a criação de uma simples pessoa. Seu mecanismo poderoso foi forjado e montado não sobre a terra, mas acima ou abaixo dela. Se apenas os anjos o tivessem construído, em vez das diferentes classes de engenheiros que agora manejam suas manivelas e válvulas de segurança, o sistema teria logo justificado a dignidade e a santidade de sua origem. [...] Era difícil duvidar que milhares de pessoas encontravam nela [i.e. na devoção católica] consolo espiritual, que não encontrariam em nossa própria e informe maneira de adoração [protestante], a qual, por outro lado, no que se refere à simpatia das almas suplicantes, só pode ser exercida em épocas determinadas e muito espaçadas. Mas aqui [no catolicismo], sempre que a fome de alimento divino atormentasse a alma, poderia ser no mesmo instante saciada. Num ou noutro altar, o incenso estava sempre 
ardendo; a missa estava sempre sendo celebrada e conduzindo para o alto a devoção daqueles que não tinham palavras próprias para as suas preces. (HAWTHORNE, 1989, p.215-216)

Em vista de tudo o que foi aqui exposto, creio que tal juízo bem poderia ter sido proferido pelos narradores de qualquer um dos três contos de Lovecraft tomados acima como objeto de especial consideração, pois é bastante coerente com a imagem do catolicismo aí apresentada. ${ }^{11}$

\section{REFERÊNCIAS}

ALMEIDA, Marcela Rodrigues Vicente Holtz de. (2008). As manifestações do gótico em Lovecraft: do castelo de Otranto ao solar de Ward. Tese (Doutorado em Estudos Literários) - FCL/UNESP. Araraquara.

ALMOND, Ian (2015). "O Islã das Trevas no Gótico Americano: motivos sufis nas estórias de H. P. Lovecraft”. In: Alfredo Bronzato da Costa Cruz (Trad.). Círculo de Giz. Rio de Janeiro, n. 1, Vol. 1, junho.

(2004). "The Darker Islam within the American Gothic: sufi motifs in the stories of H. P. Lovecraft". In: Zeitschrift fur Anglistik und Amerikanistik. Tubinga, Vol. 52, n.3.

ANGELL, Mary Potter (1909). The golden key: a sketch of mission work in latin lands. Missionary studies for children. Nova lorque: s.e.ARANTES, José Antonio (2002). "A demanda do mistério". In: MACHEN, Arthur. O terror, seguido de Ornamentos de jade. José Antonio Arantes (Trad.) (Orgs). São Paulo: lluminuras.

BUCZEK, Daniel S. (1976). "Polish-americans and the Roman Catholic Church". In: The Polish Review. Champaign, Illinois UP/PIASA, Vol. 21, n. 3, BURLESON, Donald R. (1981) "H. P. Lovecraft: the Hawthorne influence". In: Extrapolation. Brownsville, Kentucky State UP, Vol. 22, n. 3.

11 Até o fechamento deste paper, infelizmente não consegui acesso ao texto "The mad faceless god: calvinist and anti-catholic discourse in the fiction of H. P. Lovecraf", de Scott T. Merrifield, publicado em maio de 2002 na revista Vector 223. Decerto que meu próprio argumento poderia ter sido revisto ou complexificado em diálogo com a leitura deste escrito. 
CALVINO, João (1985). As Institutas, ou Tratado da Religião Cristã. Waldyr Carvalho Luz (Trad.). São Paulo: Casa Editorial Presbiteriana. CARROLL, Nöel (1999). A filosofia do horror, ou paradoxos do coração. Roberto Leal Ferreira (Trad.). Campinas: Papirus, Coleção Campo imagético, s.n.

CROWE, Frederick (1850). The Gospel in Central America - containing a sketch of the country, physical and geographical, historical and political, moral and religious: a history of the Baptist mission in British Honduras, and of the introduction of the Bible into the spanish american Republic of Guatemala with a map of the country. Londres: C. Gilpin.

CRUZ, Alfredo Bronzato da Costa (2014). “Antropologia, historicidade e terror: esboço da história cultural d'A novela da chancela negra (1895), de Arthur Machen". In: 2o Congresso Internacional Vertentes do Insólito Ficcional: (re) visões do fantástico: do centro às margens, caminho cruzados. Comunicação apresentada na $1^{\text {a }}$ sessão do simpósio 0 medo como prazer estético: (re)leituras do gótico literário (IL/UERJ, 28 de abril de 2014). Rio de Janeiro (mimeo). (Uma versão expandida deste texto encontra-se em preparação para publicação como capítulo de uma coletânea de ensaios).

DOUGLAS, Mary (2010). Pureza e perigo. Monica Siqueira Leite de Barros e Zilda Zakia Pinto (Trad.). 2.ed. São Paulo: Perspectiva, Coleção Debates, n. 120.

DOWLING, John (1845). The history of romanism, from the earliest corruptions of christianity to the present time, with full chronological table, analytical and alphabetical indexes and glossary, illustrated by numerous accurate and highly finished engravings of its ceremonies, superstitions, persecutions and historical incidents. 4.ed. Nova lorque: Edward Walker.

DUFFY, Eamon (2005). The stripping of the altars: traditional religion in England (c.1400-c.1580). 2.ed. New Haven/Londres: Yale UP.

FLOOD, Alison (2015). HP Lovecraft biographer rages against ditching of author as fantasy prize emblem. The Guardian. Publicado em 11 de novembro. In https://tinyurl.com/h9t8mhh. Acesso em 16.Jan.2017.

FRANCHOT, Jenny (1994). Roads to Rome: the antebellum protestant encounter with catholicism. Berkeley: California UP. Coleção The new historicism: studies in cultural poetics, n. 28. 
GRAHAN, Wendy C. (1999). Gothic elements and religion in Nathaniel Hawthorne's fiction. Marburgo: Tectum Verlag.

HAWTHORNE, Nathaniel (1989). O fauno de mármore. Constantino Paleólogo (Trad.) (Prefácio). Rio de Janeiro: Ediouro.

HAY, Alexander Rattray (1920). Saints and savages: Brazil's indian problem. J. H. Jowett (Prefácio). Londres: Hodder and Stoughton, 1920.

HEIDING, Fredirk \& NYMAN, Magnus (2016). Doften av rykande vekar: reformationen ur folkets perspektiv. Skellefteå. Artos \& Norma Bokförlag.

HOEVELER, Diane Long (2014). The gothic ideology: religious hysteria and anticatholicism in british popular fiction (1780-1880). Cardiff: Wales UP, Coleção Gothic Literary Studies, s.n.

HOUELlEBECQ, Michel (2005). "The myth maker". The Guardian. Publicado em 4 de junho. In https://tinyurl.com/henpchb. Acesso em 16.Jan.2017.

IRVIN, Dale T.; SUNQUIST, Scott W. (2015). História do movimento cristão mundial. Vol.2: o cristianismo moderno, de 1454 a 1800. José Raimundo Vidigal (Trad.). São Paulo: Paulus.

JOSHI, Sunand Tryambak.; SCHULTZ, David E. (2001). An H. P. Lovecraft Encyclopedia. Westport: Greenwood.

JOSHI, Sunand Tryambak (2014). A vida de H. P. Lovecraft. Bruno Gambarotto (Trad.). São Paulo: Hedra.

KUZMONVÁ, Stanislava (2010). Preaching Saint Stanis/aus: medieval sermons on Saint Stanislaus of Cracow and their role in the construction of his image and cult. Tese (Doutorado em Filosofia) - DMS/CEU. Budapeste.

LEIBER, Fritz (1966). "To Arkham and the stars: through hyperspace with Brown Jenkins. Lovecraft's contribution to speculative fiction". In: LOVECRAFT, Howard Phillips et alli. The dark brotherhood and other pieces. Sauk City: Arkham House.

LIMA, Luiz Costa (2003). O redemunho do horror: as margens do ocidente. São Paulo: Planeta do Brasil.

LORD, Bruce (2004). "The genetics of horror: sex and racism in H. P. Lovecraft's fiction". Contrasoma.com. In https://tinyurl.com/h76d93w. Acesso em 12.Jan.2017. 
LOVECRAFT, Howard Phillips; KUTTNER, Henry (1990). Letters to Henry Kuttner. David E. Schultz e Sunand Tryambak Joshi (Orgs). West Warnick: Necromonicon Press.

(2012/2). A busca onírica por Kadath. Guilherme da Silva Braga (Orgs.) (Trad.). São Paulo: Hedra. LOVECRAFT, Howard Phillips 92007). A tumba e outras histórias. Jorge Ritter (Trad.). Porto Alegre: L\&PM. Coleção L\&PM Pocket, n. 578.

(2010). Against religion: the atheist writings of H. P. Lovecraft. Sunand Tryambak Joshi (Orgs.); Christopher Hitchens (Prefácio). Nova lorque: Sporting Gentlemen.

(1995). "Discarded draft of The Shadow Over Innsmouth". In: Miscellaneous writings. Sunand Tryambak Joshi (Orgs). Sauki City: Arkham House.

(2012). O chamado de Cthulhu e outros contos. Guilherme da Silva Braga (Orgs.) (Trad.). São Paulo: Hedra.

(2013). O fantástico mundo de H. P. Lovecraft. Denílson Eahart Ricci (Orgs.); Fabiano M. Hasegawa (Prefácio); Mário Jorge Lailla Vargas et alli (Trad.). Jundiaí: Clock Tower.

(1987). O horror sobrenatural na literatura. E. F. Bleier. (Prefácio); João Guilherme Linke (Trad.). Rio de Janeiro: Francisco Alves.

LOVETT-GRAFF, Bennett (1997). "Shadows over Lovecraft: reactionary fantasy and immigrant eugenics." In: Extrapolation. Brownsville, Kentucky State UP, Vol. 38, n. 3.

MACHEN, Arthur (2007). O grande deus Pã e outros contos. José Manuel Lopes (Trad.). Lisboa: Saída de Emergência.

MANNING, Martin; ROMERSTEIN, Herbert (2004). Historical dictionary of american propaganda. Westport: Greenwood.

MARICONDA, Steven J. (1991). "Lovecraft's cosmic imagery". In: JOSHI, Sunand Tryambak; SCHULTZ, David E. (orgs.). A epicure in the terrible: a centennial anthology of essays in honor of H. P. Lovecraft. Rutherford/Cranbury: Fairleigh Dickinson UP/Associated UP.

PIEDRA, Arturo (2006). Evangelização protestante na América Latina: uma análise das razões que justificaram e promoveram a expansão protestante no continente (1830-1960). Roseli Schrader Giese (Trad.). São Leopoldo/Quito: Sinodal/CLAI, v.2. 
PIKE, Fredrick B. (1998). The United States and Latin America: myths and stereotypes of civilization and nature. Austin: Texas UP.

PRICE, Robert M.; ALETTI, Steffan B. (orgs.). The Necronomicon: selected stories and essays concerning the blasphemous tome of the Mad Arab (rev. e ampl.). Earl Geier et alli (Ilustração). 2.ed. Oakland: Chaosium.

PRICE, Robert M. (1981). "Lovecraft's concept of blasphemy". In: Crypt of Cthulhu. West Warnick, Necromonicon Press, n. 1, novembro.

(1995). "The mad god: an introduction to the Azathoth cycle". In: PRICE, Robert M. (orgs.). The Azathoth cycle: tales of the blind idiot god. Oakland: Chaosium. REED, Rebecca Theresa (1835). Six months in a convent, or the narrative of Rebecca Theresa Reed, who was under the influence of the roman catholics about two years, and an inmate of the Ursuline convent on Mount Benedict, Charlestown, Massachussets, nearly six months, in the years 1831 and 1832. Nova lorque/ Filadélfia/Cincinnati: Nelson Hall/William Marshall and Companhy/C. P. Barnes. SAGE. Victor (1988). Horror fiction in the protestant tradition. Nova Iorque: Sy. Martin's Press.

SAID, Edward W. (2007). Orientalismo: o Oriente como invenção do Ocidente. Rosaura Eichenberg (Trad.). São Paulo: Companhia das Letras.

SCHULTZ, David E. (1991). "From microcosm to macrocosm: the growth of Lovecraft's cosmic vision". In: JOSHI, Sunand Tryambak; SCHULTZ, David E. (orgs.). A epicure in the terrible: a centennial anthology of essays in honor of $H . P$. Lovecraft. Rutherford/Cranbury: Fairleigh Dickinson UP/Associated UP.

SCHULTZ, Jeffrey D.; WEST, John G.; MACLEAN, Iain S. (1999) Encylopedia of religion in american politics. Westport: Greenwood, Coleção American political landscape, n. 2.

SILVA, Carlos Eduardo Lins da. (2009) "Do alto da colina: religião e política na história dos Estados Unidos". In: (orgs.). Uma nação com alma de igreja: religiosidade e políticas públicas nos Estados Unidos. São Paulo: Paz e Terra.

SNODGRASS, Mary Ellen (2005). Encyclopedia of gothic literature. Nova lorque: Facts On File.

STARK, Rodney (2016). Bearing false witness: debunking centuries of anticatholic history. West Conshohocken: Templeton. 
STERNE, Evelyn Savidge (2003). Ballots and Bibles: ethnic politcs and the Catholic Church in Providence. Ithaca: Cornell UP. Coleção Cushwa Center Studies of Catholicism in Twentieth-Century America, s.n.

THOMAS, Keith. (1991). Religião e o declínio da magia: crenças populares na Inglaterra (séculos XVI e XVII). Denise Bottman e Tomás Rosa Bueno (Trad.). São Paulo: Companhia das Letras.

VOIGT, Gilbert P. (1946). "Hawthorne and the Roman Catholic Church". In: The New England Quarterly. Boston, Massachusetts UP, Vol. 19, n. 3, setembro. 